Review Article

\title{
MINI REVIEW: INSIGHTS ON INSTRUMENTAL ANALYSIS OF OMBITASVIR, PARITAPREVIR AND RITONAVIR
}

\author{
ROSHDY E. SARAYA ${ }^{1}$, MAGDA ELHENAWEE ${ }^{2}$, HANAA SALEH ${ }^{2}$, MAHMOUD M. SEBAIY3*
}

1Department of Pharmaceutical Analytical Chemistry, Faculty of Pharmacy, Port Said University, Port Said, 42511, Egypt, 2,3Department of Medicinal Chemistry, Faculty of Pharmacy, Zagazig University, Zagazig, 44519, Egypt

Email: mmsebaiy@zu.edu.eg

Received: 19 Dec 2020 Revised and Accepted: 01 Feb 2021

\section{ABSTRACT}

In this literature review, we will introduce most of the up-to-date reported methods that have been developed for the determination of Ombitasvir, Paritaprevir and Ritonavir in their pure form, combined form with other drugs combined form with degradation products, and in biological samples. Most of reported methods includes spectrophotometric and chromatographic methods specially HPLC and HPTLC.

Keywords: HCV, Ombitasvir, Paritaprevir, Ritonavir, Degradation products, Biological samples

(C) 2021 The Authors. Published by Innovare Academic Sciences Pvt Ltd. This is an open access article under the CC BY license (http://creativecommons.org/licenses/by/4.0/) DOI: http://dx.doi.org/10.22159/ijcr.2021v5i2.153. Journal homepage: https://ijcr.info/index.php/journal

\section{INTRODUCTION}

Infection due to hepatitis $\mathrm{C}$ virus (HCV) is a leading cause for severe chronic liver disease, which can result in progressive liver damage such as cirrhosis and hepatocellular carcinoma. HCV is a single-stranded RNA virus that is categorized into nine distinct genotypes, with genotype 1 being the most common in the United States and affecting $72 \%$ of all chronic HCV patients [1]. Ombitasvir (OMB) is an inhibitor of NS5A, a protein essential for viral replication and virion assembly. The barrier for the development of resistance to NS5A inhibitors is lower than that of NS5B inhibitors, another class of DAAD [2]. In addition, the combination of OMB, the ritonavir-boosted PI paritaprevir, and the non-nucleoside polymerase inhibitor dasabuvir with or without ribavirin was approved for patients with HCV genotype 1 [3]. Treatment with direct acting antivirals such as OMB is associated with very minimal side effects, with the most common being headache and fatigue; Lack of significant side effects and short duration of therapy is a considerable advantage over older interferon-based regimens, which were limited by infusion site reactions, reduced blood count, and neuropsychiatric effects [4]. Paritaprevir (PAR) prevents viral replication by inhibiting the NS3/4A serine protease of HCV. Following viral replication of HCV genetic material and translation into a single polypeptide, Nonstructural Protein 3 and its activating cofactor Nonstructural Protein 4A are responsible for cleaving genetic material into the following structural and nonstructural proteins required for assembly into mature virus: NS3, NS4A, NS4B, NS5A, and NS5B [5].

As such, in this literature review, we will introduce most of the up-to-date reported methods that have been developed for the determination of $\mathrm{OMB}, \mathrm{PAR}$ and RIT in different matrices.

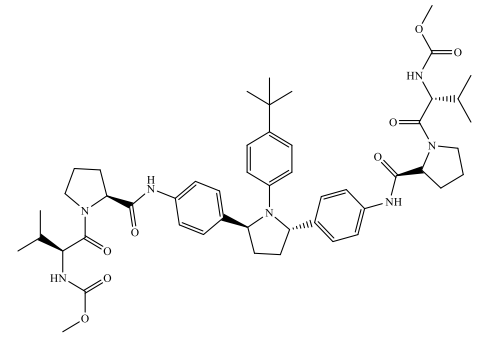

OMB

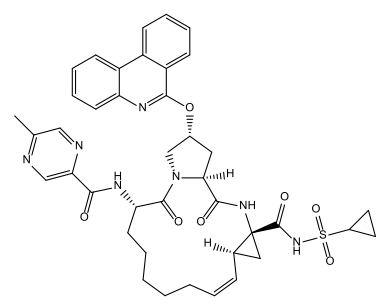

PAR

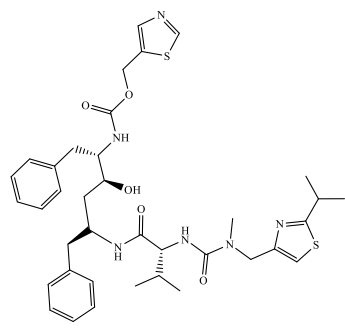

RIT

Fig. 1: Chemical structures of ombitasvir (OMB), paritaprevir (PAR), and ritonavir (RIT), Ombitasvir (OMB) 


\section{Review of analytical methods}

Various techniques were used for the analysis of OMB in pure forms, in their pharmaceutical formulations and in biological fluids. The available reported methods in the literature can be summarized as follows:

Table 1: Chromatographic methods for determination of OMB

\begin{tabular}{|c|c|c|c|c|}
\hline Matrix & Column & Mobile phase & System & Ref. \\
\hline Plasma & UPLC BEH $\mathrm{C}_{18}$ & Ammonium acetate 5 mmol (pH 9.5): ACN (gradient elution). & UHPLC-MS/MS & [6] \\
\hline Tablet & Hypersil BDS $\mathrm{C}_{18}$ column & $\begin{array}{l}0.01 \mathrm{~N} \% \mathrm{mmol} \text { phosphate buffer }(\mathrm{pH} 3) \text { and acetonitrile }(35: 65 \text {, } \\
\mathrm{v} / \mathrm{v}) \text {. }\end{array}$ & HPLC-DAD $254 \mathrm{~nm}$ & [7] \\
\hline plasma & Intersil ODS $\mathrm{C}_{18}$ & $20 \%$ ACN: $20 \%$ Methanol, $60 \% 1 \mathrm{mmol} \mathrm{NH}_{4} \mathrm{H}_{2} \mathrm{PO}_{4}$ Buffer (PH 6.5). & HPLC-UV $230 \mathrm{~nm}$ & [8] \\
\hline Liver & Waters Acquity BEH $\mathrm{C}_{18}$ column & A gradient elution with $0.1 \%$ FA in water and ACN. & UHPLC-MS/MS & [9] \\
\hline
\end{tabular}

\section{Other methods}

A novel micellar electrokinetic capillary chromatographic (MEKC) method was developed for the simultaneous determination of OMB, PAR, RIT and dasabuvir (DAS). The technique was based on the separation of all of the selected drugs in a deactivated fused silica capillary with a background electrolyte solution (BGE) composed of $25 \mathrm{mM}$ phosphate buffer with $30 \mathrm{mM}$ sodium dodecyl sulphate (SDS) (the pH of the aqueous phase was adjusted to 8) mixed with ethanol in a ratio of $65: 35(\mathrm{v} / \mathrm{v})$. The capillary and sample temperature was maintained at $24{ }^{\circ} \mathrm{C}$, and the detection was performed at $239 \mathrm{~nm}$. The electrophoresis was performed by applying a high voltage ( $30 \mathrm{kV})$ to the capillary [10].

\section{Paritaprevir (PAR)}

\section{Review of analytical methods}

Various techniques were used for the analysis of PAR in pure forms, in their pharmaceutical formulations and in biological fluids. The available reported methods in the literature can be summarized as follows:

Table 2: Chromatographic methods for determination of PAR

\begin{tabular}{|c|c|c|c|c|}
\hline Matrix & Column & Mobile phase & System & Ref. \\
\hline Plasma & UPLC BEH C 18 & Ammonium acetate $5 \mathrm{mmol}$ (pH 9.5) and acetonitrile (gradient elution). & UHPLC-MS/MS & [6] \\
\hline Tablet & Hypersil BDS $\mathrm{C}_{18}$ column & $0.01 \mathrm{~N} \% \mathrm{mmol}$ phosphate buffer $(\mathrm{pH} 3)$ and acetonitrile $(35: 65, \mathrm{v} / \mathrm{v})$ & HPLC-DAD $254 \mathrm{~nm}$ & [7] \\
\hline $\begin{array}{l}\text { Rat } \\
\text { liver }\end{array}$ & Acquity $\mathrm{BEH} \mathrm{C}_{18}$ & $\begin{array}{l}\text { A gradient elution with }(95: 5: 0.1 \mathrm{v} / \mathrm{v} / \mathrm{v}) \text {, water: acetonitrile: formic acid } \\
\text { and (acetonitrile containing } 0.1 \% \text { formic acid). }\end{array}$ & UPLC-MS/MS & [11] \\
\hline plasma & Intersil ODS $\mathrm{C}_{18}$ & $20 \%$ Acetonitrile, $20 \%$ Methanol, $60 \% 1 \mathrm{mmol} \mathrm{NH}_{4} \mathrm{H}_{2} \mathrm{PO}_{4}$ Buffer (PH 6.5). & HPLC-UV $230 \mathrm{~nm}$ & [8] \\
\hline Liver & Waters Acquity BEH $\mathrm{C}_{18}$ & A gradient elution with $0.1 \%$ FA in water and ACN. & UHPLC-MS/MS & [9] \\
\hline
\end{tabular}

\section{Ritonavir (RIT)}

\section{Review of analytical methods}

Various techniques were used for the analysis of RIT in pure forms, in their pharmaceutical formulations and in biological fluids. The available reported methods in the literature can be summarized as follows:

Table 3: Spectrophotometric methods for determination of RIT

\begin{tabular}{|c|c|c|c|}
\hline Drugs & Method or reagent & $\lambda_{\max }$ & Ref \\
\hline $\begin{array}{l}\text { RIT and Atazanavir } \\
\text { (ATV) }\end{array}$ & $\begin{array}{l}\text { Ratio spectra derivative method, Area under } \\
\text { curve method. }\end{array}$ & $\begin{array}{l}280.01 \mathrm{~nm}(\mathrm{ATV}), 286.12 \mathrm{~nm}(\mathrm{RIT}), 246.97-252.03 \mathrm{~nm} \\
\text { (ATV): } 240.78-244.16 \mathrm{~nm}(\mathrm{RIT})\end{array}$ & [12] \\
\hline RIT & $\begin{array}{l}\text { First-order derivative method, under curve } \\
\text { method. }\end{array}$ & $\begin{array}{l}253.2 \mathrm{~nm}(\mathrm{RIT}) \\
237-242 \mathrm{~nm}(\mathrm{RIT})\end{array}$ & [13] \\
\hline RIT and lopinavir & First-order derivative method. & $246.70 \mathrm{~nm}$ (RIT) and $278.10 \mathrm{~nm}$ (lipinavir) & [14] \\
\hline $\begin{array}{l}\text { Sofosbuvir, Lamivudine, } \\
\text { and RIT }\end{array}$ & Silver nanoparticles synthesis. & $\begin{array}{l}421 \mathrm{~nm} \text { for Sofosbuvir and RIT and at } 425 \mathrm{~nm} \text { for } \\
\text { Lamivudine }\end{array}$ & [15] \\
\hline
\end{tabular}

Chromatographic methods for determination of RIT

Table 4: HPLC methods for determination of RIT

\begin{tabular}{|c|c|c|c|c|}
\hline Matrix & Column & Mobile phase & System & Ref. \\
\hline Plasma & UPLC BEH $\mathrm{C}_{18}$ & Ammonium acetate $5 \mathrm{mmol}$ (pH 9.5) and acetonitrile (gradient elution). & UHPLC-MS/MS & [6] \\
\hline Tablet & $\begin{array}{l}\text { Hypersil BDS } \mathrm{C}_{18} \\
\text { column }\end{array}$ & $0.01 \mathrm{~N} \% \mathrm{mmol}$ phosphate buffer $(\mathrm{pH} 3)$ and acetonitrile $(35: 65, \mathrm{v} / \mathrm{v})$ & HPLC-DAD $254 \mathrm{~nm}$ & [7] \\
\hline Plasma & Aquasil ${ }^{\circledR} \mathrm{C}_{18}$ & A gradiant elution with $0.05 \%$ formic acid in either water or methanol. & HPLC-MS/MS & [16] \\
\hline Rat liver & Acquity $\mathrm{BEH}_{18}$ & $\begin{array}{l}\text { A gradient elution with }(95: 5: 0.1 \mathrm{v} / \mathrm{v} / \mathrm{v}) \text {, water: acetonitrile: formic acid } \\
\text { and (acetonitrile containing } 0.1 \% \text { formic acid). }\end{array}$ & UPLC-MS/MS & [11] \\
\hline plasma & Intersil ODS $\mathrm{C}_{18}$ & $\begin{array}{l}20 \% \text { Acetonitrile, } 20 \% \text { Methanol, } 60 \% 1 \mathrm{mmol} \mathrm{NH}_{4} \mathrm{H}_{2} \mathrm{PO}_{4} \text { Buffer }(\mathrm{PH} \\
6.5) \text {. }\end{array}$ & HPLC-UV $230 \mathrm{~nm}$ & [8] \\
\hline
\end{tabular}




\begin{tabular}{|c|c|c|c|c|}
\hline Liver & $\begin{array}{l}\text { Waters Acquity BEH } \mathrm{C}_{18} \\
\text { column }\end{array}$ & A gradient elution with $0.1 \%$ FA in water and ACN. & UHPLC-MS/MS & [9] \\
\hline Plasma & OmniSpher $\mathrm{C}_{18}$ column & $\begin{array}{l}\text { A gradient elution with } \mathrm{ACN}: 50 \mathrm{mmol} / \mathrm{l} \text { potassium phosphate }(\mathrm{pH} \\
5.75) \text {. }\end{array}$ & HPLC-UV at $215 \mathrm{~nm}$ & [17] \\
\hline Plasma & $\mathrm{C}_{18}$ column & ACN: 50 mmol phosphate buffer (pH 5.63) (40:60, v/v). & HPLC-UV at $215 \mathrm{~nm}$ & [18] \\
\hline Plasma & $\mathrm{C}_{18}$ Column & $\begin{array}{l}\text { Acetonitrile plus distilled water within } 25 \mathrm{mmol} \text { sodium acetate and } 25 \\
\text { mmol hexane-1-sulfonic acid and adjusted to } \mathrm{pH} 6.0(40.5: 59.5, \mathrm{v} / \mathrm{v}) \text {. }\end{array}$ & HPLC-UV at $239 \mathrm{~nm}$ & [19] \\
\hline Plasma & NovaPak $\mathrm{C}_{18}$ column & $\begin{array}{l}\text { ACN, methanol and tetramethylammonium perchlorate in dilute } \\
\text { aqueous TFA (45: 5: } 50 \mathrm{v} / \mathrm{v} / \mathrm{v}) \text {. }\end{array}$ & HPLC-UV at $205 \mathrm{~nm}$ & [20] \\
\hline Plasma & $\mathrm{C}_{18}$ column & $\begin{array}{l}\text { ACN, methanol and } 0.01 \mathrm{M} \text { tetramethylammonium perchlorate in } 0.1 \% \\
\text { aqueous TFA }(40: 5: 55 \mathrm{v} / \mathrm{v} / \mathrm{v}) \text {. }\end{array}$ & HPLC-UV at $205 \mathrm{~nm}$ & [21] \\
\hline Plasma & Inertsil ODS column & ACN: 5 mmol ammonium acetate buffer (pH 3.5) (80: $20 \mathrm{v} / \mathrm{v})$ & HPLC-MS/MS & [22] \\
\hline Tablet & phenomenex-Luna $\mathrm{C}_{18}$ & Acetonitrile: $0.5 \%$ TEA (pH 5) $(67: 33 \%, \mathrm{v} / \mathrm{v})$ & HPLC-DAD at $205 \mathrm{~nm}$ & [23] \\
\hline Plasma & Waters UPLC $\mathrm{C}_{18}$ column & 10 mmol AF (pH 4.0) adjusted with FA: methanol (10:90 v/v). & UPLC-MS/MS & [24] \\
\hline Tablet & A symmetry $\mathrm{C}_{18}$ & Phosphate buffer (pH 4): ACN (50:50). & HPLC-UV at $239 \mathrm{~nm}$ & [25] \\
\hline Plasma & Acquity UPLC $\mathrm{C}_{18}$ & $0.1 \%$ FA: methanol $(40: 60, \mathrm{v} / \mathrm{v})$ & UPLC-MS/MS & [26] \\
\hline Tablet & a Hypersil BDS- $\mathrm{C}_{18}$ & Phosphate buffer (pH3.4): ACN (50:50, v/v). & HPLC-UV at $250 \mathrm{~nm}$ & [27] \\
\hline Tablet & Waters UPLC $\mathrm{C}_{18}$ column & $\begin{array}{l}\text { A gradient elution with } 0.01 \mathrm{M} \text { potassium dihydrogen phosphate }(\mathrm{pH} \\
\text { 3.5): ACN }\end{array}$ & UPLC-MS/MS & [28] \\
\hline Tablet & a Waters Symmetry $\mathrm{C}_{18}$ & $\begin{array}{l}\text { ACN: } 2 \text { mmol ammonium acetate containing 0.01\% FA (v/v) (70:30 } \\
\text { v/v). }\end{array}$ & HPLC-MS/MS & [29] \\
\hline Tablet & An Agilent $\mathrm{TC}-\mathrm{C}_{18}$ & Methanol: ACN: water in the $(35: 41.5: 23.5 \mathrm{v} / \mathrm{v} / \mathrm{v})$ & HPLC-UV at $222 \mathrm{~nm}$ & [30] \\
\hline Tablet & a Thermo Hypersil $\mathrm{C}_{18}$ & $0.05 \mathrm{M} \mathrm{KH}_{2} \mathrm{PO}_{4}$ buffer $(\mathrm{pH} 3.0):$ ACN $(45: 55 \mathrm{v} / \mathrm{v})$ & HPLC-UV at $254 \mathrm{~nm}$ & [31] \\
\hline Tablet & An Agilent TC- $\mathrm{C}_{18}$ & ACN: $0.05 \mathrm{M}$ phosphoric acid $(55: 45, \mathrm{v} / \mathrm{v})$ & HPLC-UV at $240 \mathrm{~nm}$ & [32] \\
\hline Tablet & a $\mathrm{C}_{18}$ column & 0.06 M SDS: 1-pentanol (pH 7) (97.5: $2.5 \mathrm{v} / \mathrm{v})$ & HPLC-UV at $214 \mathrm{~nm}$ & [33] \\
\hline Tablet & Symmetry $\mathrm{C}_{18}$ & phosphate buffer (pH 4.0): ACN (45:55 \% v/v). & HPLC-UV at $237 \mathrm{~nm}$ & [34] \\
\hline tablet & $\begin{array}{l}\text { RP- } \mathrm{C}_{18} \text { Kinetix core- } \\
\text { shell column }\end{array}$ & $\begin{array}{l}\text { (0.15 M sodium lauryl sulfate and } 0.01 \mathrm{M} \text { sodium dihydrogen } \\
\text { phosphate, } \mathrm{pH} 6.2 \text { ) and ethanol (56:44). }\end{array}$ & HPLC-Uv at 254 & [35] \\
\hline
\end{tabular}

Table 5: HPTLC methods for determination of RIT

\begin{tabular}{|c|c|c|c|c|}
\hline Matrix & Column & Mobile phase & System & Ref. \\
\hline $\begin{array}{l}\text { Tablet, vials, and } \\
\text { plasma }\end{array}$ & silica-gel $60 \mathrm{~F}_{254}$ plate & Chloroform-methanol-ethyl acetate $(6: 2: 2 \mathrm{v} / \mathrm{v})$ & UV-302 nm & [35] \\
\hline Tablet & silica-gel $60 \mathrm{~F}_{254}$ plate & Ethyl acetate: ethanol: toluene: diethylamine $(7: 2.0: 0.5: 0.5, \mathrm{v} / \mathrm{v} / \mathrm{v} / \mathrm{v})$. & UV-266 nm & [36] \\
\hline Tablet & silica-gel $60 \mathrm{~F}_{254}$ plate & Ethyl acetate: Toluene: methanol (7.5: 2: $0.5 \mathrm{v} / \mathrm{v} / \mathrm{v})$ & UV-234 nm & [37] \\
\hline Tablet & silica-gel $60 \mathrm{~F}_{254}$ plate & Chloroform: ethyl acetate: acetone $(5: 2: 3, \mathrm{v} / \mathrm{v} / \mathrm{v})$. & $\mathrm{UV}-244 \mathrm{~nm}$ & [38] \\
\hline
\end{tabular}

\section{CONCLUSION}

This literature review represents an up to date survey about all reported methods that have been developed for determination of Ombitasvir, Paritaprevir and Ritonavir in their pure form, combined form with other drugs, combined form with degradation products, and in biological samples such as liquid chromatography, spectrophotometry, electrochemistry, etc.

\section{FUNDING}

Nil

\section{AUTHORS CONTRIBUTIONS}

All the authors have contributed equally.

\section{CONFLICT OF INTERESTS}

\section{Declared none}

\section{REFERENCES}

1. Edwards DJ. Access to hepatitis C medicines. Bull World Health Organization 2015;93:799-805.

2. Sabrina Bagaglio, Caterina Uberti Foppa, Giulia Morsica. Resistance mechanisms in hepatitis C virus: implications for direct-acting antiviral use. Drugs 2017;77:1043-55.

3. Robert P Myers. An update on the management of chronic hepatitis C: Consensus guidelines from the canadian association for the study of the liver. Can J Gastroenterol Hepatol 2015;29:19-34.

4. Geoffrey Dusheiko. Side effects of $\alpha$ interferon in chronic hepatitis C. Hepatol 1997;26:112S-21S.

5. Darius Moradpour and François Penin, Hepatitis $\mathrm{C}$ virus proteins: from structure to function, in Hepatitis $\mathrm{C}$ virus: from molecular virology to antiviral therapy. Curr Top Microbiol Immunol 2013;369:113-42.

6. Alessandra Ariaudo. A UHPLC-MS/MS method for the quantification of direct antiviral agents simeprevir, daclatasvir, ledipasvir, sofosbuvir/GS-331007, dasabuvir, ombitasvir and paritaprevir, together with ritonavir, in human plasma. J Pharm Biomed Anal 2016;125:369-75.

7. Syed Ibrahim Baje, B Jyothi, N Madhavi. RP-HPLC method for simultaneous estimation of ritonavir, ombitasvir and paritaprevir in tablet dosage forms and their stress degradation studies. Int J Appl Pharm 2019:11:193-210.

8. Phani RS Ch, KRS Prasad, Useni Reddy Mallu. New analytical HPLC method development and validation for the simultaneous quantification of paritaprevir ombitasvir and ritonavir in spiked human plasma. Orient Jo Chem 2017:33:2363-69.

9. Andrew J Ocque. Ultra-performance liquid chromatography-tandem mass spectrometry for the determination of direct-acting antiviral drugs in human liver fine-needle aspirates. J Chromatogr B 2017:1052:103-9. 
10. Nourah Zoman Al-Zoman, Hadir Mohamed Maher, Amal Al-Subaie. Eco-friendly micellar electrokinetic capillary chromatographic method for the simultaneous determination of newly developed antiviral agents in pharmaceutical formulations. J Liq Chromatogr Relat Technol 2018;42:1-9.

11. Andrew J Ocque. Development and validation of a UPLC-MS/MS method for the simultaneous determination of paritaprevir and ritonavir in rat liver. Bioanal 2016;8:1353-63.

12. Nilesh A Bari. Spectrophotometric simultaneous determination of atazanavir and ritonavir in combined tablet dosage form by ratio derivative and area under curve method. Der Pharm Chem 2012;4:208-13.

13. Anindita Behera. Method development, validation and stability study of ritonavir in bulk and pharmaceutical dosage form by spectrophotometric method. Chronicl Young Sci 2011;2:161-7.

14. VP Nagulwar and KP Bhusari. Development of UV spectrophotometric first order derivative method for the simultaneous estimation of ritonavir and lopinavir in combined tablet dosage form. Int J Pharm Sci Res 2012;3:2317-20.

15. Saraya RE, M Elhenawee, H Saleh. Silver nanoparticles synthesis for sensitive spectrophotometric determination of sofosbuvir, lamivudine, and ritonavir in pure forms and pharmaceutical dosage forms. J AOAC Int 2020;103:140-7.

16. J Byung Hwaung. Simultaneous determination of 17 antiretroviral drugs in human plasma for quantitative analysis with liquid chromatography-tandem mass spectrometry. Biomed Chromatogr 2007;21:1095-104.

17. JAH Verweij-van Droste, CPWGM Wissen, DM Burger. Simultaneous determination of the HIV drugs indinavir, amprenavir, saquinavir, ritonavir, lopinavir, nelfinavir, the nelfinavir hydroxymetabolite M8, and nevirapine in human plasma by reversed-phase high-performance liquid chromatography. Ther Drug Monitor 2003;25:393-9.

18. PWH Verweij-van Hugen. Simultaneous determination of the HIV-protease inhibitors indinavir, nelfinavir, saquinavir and ritonavir in human plasma by reversed-phase high-performance liquid chromatography. J Chromatogr B: Biomed Scia Appl 1999;727:139-49.

19. RPG Van Heeswijk. Simultaneous quantitative determination of the HIV protease inhibitors amprenavir, indinavir, nelfinavir, ritonavir and saquinavir in human plasma by ion-pair high-performance liquid chromatography with ultraviolet detection. J Chromatogr B: Biomed Sci Appl 1998;719:159-68.

20. Yoshiko Usami. A simple HPLC method for simultaneous determination of lopinavir, ritonavir and efavirenz. Chem Pharm Bull 2003;51:715-8.

21. Kennan C Marsh, Erin Eiden, Edith McDonald. Determination of ritonavir, a new HIV protease inhibitor, in biological samples using reversedphase high-performance liquid chromatography. J Chromatogr B Biomed Sci Appl 1997;704:307-13.

22. Rajasekhar Damaramadugu. Simultaneous determination of ritonavir and lopinavir in human plasma after protein precipitation and LC-MSMS. Chromatographia 2010;71:815-24.

23. I Ponnilavarasan. RP-HPLC method for simultaneous estimation of antiretroviral drugs lopinavir and ritonavir in the tablet dosage form. Dig J Nanomat Biostru 2010;5:771-8.

24. Manish Yadav. Application of a rapid and selective method for the simultaneous determination of protease inhibitors, lopinavir and ritonavir in human plasma by UPLC-ESI-MS/MS for bioequivalence study in Indian subjects. J Pharm Biomed Anal 2009;49:1115-22.

25. K Chiranjeevi. Development and validation of RP-HPLC method for quantitative estimation of ritonavir in bulk and pharmaceutical dosage forms. Int J Pharm Sci Res 2011;2:336-40.

26. Tulsi Das Mishra. Simultaneous quantitation of HIV-protease inhibitors ritonavir, lopinavir and indinavir in human plasma by UPLC-ESI-MSMS. J Chromatogr Sci 2012;50:625-35.

27. P Saritha. Stability-indicating liquid chromatographic method for the simultaneous determination of atazanavir and ritonavir in pharmaceutical formulation. Int J Pharm Sci Res 2013;4:2659-66.

28. Srinivasarao Koppala. Development and validation of a simple, sensitive, selective and stability-indicating RP-UPLC method for the quantitative determination of ritonavir and its related compounds. J Chromatogr Sci 2014;53:662-75.

29. Perry G Wang. Validation and application of high-performance liquid chromatography-tandem mass spectrometric method for simultaneous quantification of lopinavir and ritonavir in human plasma using semi-automated 96-well liquid-liquid extraction. J Chromatogr A 2006;1130:302-7.

30. D Sathis Kumar. Method development and validation of valacyclovir hydrochloride and ritonavir in tablet dosage form using reverse-phase high-performance liquid chromatography. J Technol 2015;76:39-45.

31. MP Gadhvi. Development and validation of RP-HPLC method for simultaneous estimation of atazanavir and ritonavir in their combined tablet dosage form. Res J Pharm Technol 2013;6:200-3.

32. Shivanand N Hiremath, Charushila H Bhirud. Development and validation of a stability-indicating HPLC method for the simultaneous analysis of lopinavir and ritonavir in fixed-dose combination tablets. J Taibah Univ Med Sci 2015;10:271-7.

33. Juan Peris Vicente. Use of micellar liquid chromatography to analyze darunavir, ritonavir, emtricitabine, and tenofovir in plasma. J Sep Sci 2014;37:2825-32.

34. J Venkatesh. Reverse phase high-performance liquid chromatographic estimation of atazanavir and ritonavir in pharmaceutical dosage form. Asian J Res Chem 2013;6:855-8.

35. Ibrahim AE. Development and validation of eco-friendly micellar-HPLC and HPTLC-densitometry methods for the simultaneous determination of paritaprevir, ritonavir and ombitasvir in pharmaceutical dosage forms. Heliyon 2019;5:e01518.

36. Dhara J Patel. Simultaneous HPTLC determination of lopinavir and ritonavir in combined dosage form. Asian J Pharm Clin Res 2011;4:59-61.

37. RK Nanda, Pradeep B Yadav, AA Kulkarni. Stability-indicating validated HPTLC method for simultaneous estimation of atazanavir sulfate and ritonavir in pharmaceutical dosage form. Asian Res Chem 2011;4:1381-4.

38. Manoj Gadhvi. Simultaneous determination of ritonavir and atazanavir in combined tablet dosage form by HPTLC. Asian J Biomed Pharm Sci 2012;2:15-9. 